\title{
Analisis Keaktifan Siswa dalam Proses Pembelajaran Daring di Masa Pandemi COVID-19
}

\section{Al Halik*1, Zamratul Aini ${ }^{2}$}

${ }^{1}$ Program Studi Bimbingan Penyuluhan Islam, Institut Agama Islam Negeri (IAIN) Metro, Lampung, Indonesia, ${ }^{2}$ Program Studi Bimbingan dan Konseling Islam, Universitas Islam

Negeri (UIN) Ar-Raniry, Banda Aceh, Indonesia.

*1) Corresponding author, Ðe-mail: alhalik@metrouniv.ac.id

$\begin{array}{ccc}\text { Received: } & \text { Accepted: } & \text { Published: } \\ \text { 19 } \text { August } 2020 & \text { 02 November 2020 } & \text { 29 December 2020 }\end{array}$

\begin{abstract}
The goal of all learning efforts is for students to learn. In learning, students are subjects who are actively learning. Student success in learning is influenced by the quality of the student's activity. The purpose of this study was to determine the level of student activity in online learning during the COVID-19 pandemic from the aspects of visual activity, oral activity, listening activity, writing activity, emotional activity,and mental activity.This research Uses a descriptive quantitative approach. Data collection was carried out at two locations, namely the Vocational High School (SMK) and State Madrasah Aliyah (MAN) of 144 students. The instrument used to collect the data was a Scale of Students Active by Zamratul Aini, and questionnaires are distributed online through the Google Forms application. The results showed that in general the activeness of students in the online learning process was in the high category. The results of the research can be used as input for the counselor in planning, designing, implementing, and evaluating guidance and counseling programs according to the analysis of student needs. Besides, it can also serve as input for the Principal to provide support to implementers of guidance and counseling service activities. In its implementation, counselors need to collaborate with various parties, both school personnel and other parties outside the school, so that the success of these guidance and counseling services can be achieved optimally.
\end{abstract}

Keywords: The Activeness of Students, Online Learning, COVID-19, School Counseling

\begin{abstract}
Abstrak
Upaya pembelajaran yang dilakukan semuanya bertujuan agar siswa belajar. Siswa merupakan subjek yang aktif dalam pembelajaran. Keberhasilan siswa dalam belajar dipengaruhi oleh kualitas keaktifan siswa tersebut. Tujuan dari penelitian ini adalah untuk mengetahui tingkat keaktifan siswa dalam pembelajaran daring di masa pandemi COVID-19 dari aspek aktivitas visual, aktivitas lisan, aktivitas mendengarkan, aktivitas menulis, aktivitas emosional, serta aktivitas mental, dengan melakukan penelitian kuantitatif jenis deskriptif. Pengumpulan data dilakukan pada dua lokasi yaitu Sekolah Menengah Kejuruan (SMK) dan Madrasah Aliyah Negeri (MAN) dengan jumlah 144 orang siswa. Data dikumpulkan melalui angket Keaktifan Siswa Zamratul Aini yang disebarkan secara online melalui aplikasi Google Formulir. Hasil penelitian menunjukkan bahwa secara umum keaktifan siswa dalam proses pembelajaran daring berkategori tinggi. Hasil penelitian dapat digunakan sebagai need assisment dalam perencanaan, perancangan, pelaksanaan dan pengevaluasian program BK. Data dalam kebijakan dukungan kepala sekolah atas pelaksanaan kegiatan BK, serta membentuk kerjasama guru matapelajaran dan BK untuk meningkatkan keberhasilan layanan BK secara optimal.
\end{abstract}

Kata Kunci : Keaktifan Siswa, Pembelajaran Daring, COVID-19, Konseling Sekolah

How to Cite: Halik, A., \& Zamratul, A. (2020). Analisis Keaktifan Siswa dalam Proses Pembelajaran Daring di Masa Pandemi COVID-19. ENLIGHTEN: Jurnal Bimbingan Konseling Islam, 3(2), 131-141. https://doi.org/10.32505/enlighten.v3i2.1887 


\section{PENDAHULUAN}

Masyarakat dunia akhir-akhir ini sedang menghadapi kesusahan karena dilanda musibah berupa wabah Virus Corona atau dikenal juga dengan sebutan COVID-19. Setiap hari kasus positif di Indonesia semakin bertambah (Coronavirus Update (Live), t.t.). Kondisi ini membawa perubahan pembaharuan kebijakan untuk diterapkan temasuk di dunia pendidikan. Melalui Kementerian Pendidikan dan Kebudayaan serta Kementerian Agama Repubelik Indonesia, sejak pertengahan Maret 2020 menerapkan kebijakan proses pembelajaran dilakukan dari rumah sebagai upaya untuk mencegah penyebaran COVID19.

Sistem pembelajaran secara signifikan berubah akibat dari pandemi COVID-19 dari proses interaksi siswa guru secara tatap muka langsung menjadi interaksi dalam jaringan (daring). Pembelajaran daring adalah proses pembelajaran yang berjalan dengan memanfaatkan jaringan internet dengan akses, koneksi, dan fleksibilitas dalam memunculkan berbagai jenis interaksi pembelajaran (Moore dkk., 2011). Interaksi yang terjalin antara siswa dan guru menggunakan aplikasi online yang telah banyak tersedia, seperti google classroom, zoom meeting, whatsapp dan aplikasi lainnya.

Pembelajaran yang dilakukan dengan daring atau jarak jauh diharapkan mampu memenuhi standar pendidikan, di mana siswa dan guru masih bisa saling terhubung melalui pemanfaatan teknologi seperti komputer atau gadget. Saling terhubungnya siswa dan guru melalui teknologi dengan jarak jauh biasanya mengunakan proses pembelajaran dengan metode e-learnig. E-learning diartikan sebagai pembelajaran yang menggunakan teknologi yang saling terhubung antara siswa dengan guru, atau mahasiswa dengan dosen, di mana materi pembelajaran dikirim ke siswa secara jauh melalui jaringan komputer dan gadget.

Perubahan yang drastis ini tentu membuat para guru dan siswa harus mulai membiasakan diri, karena pembelajaran daring tidak semua siswa dan guru terbiasa melakukannya, apalagi guru yang masih belum mahir menggunakan teknologi. Perubahan budaya belajar ini menjadi salah satu kendala bagi siswa, karena selama ini siswa sudah terbiasa melalui tatap muka, sehingga pembelajaran daring siswa perlu untuk beradaptasi dengan proses pembelajaran yang baru ini, secara tidak langsung mempengaruhi daya serap dan keaktifan belajar siswa (Purwanto dkk., 2020).

Pembelajaran secara daring menuntut siswa untuk mampu mengatur dan mengarahkan diri secara mandiri. Setidaknya ada empat komponen penting yang membangun budaya belajar; (1) siswa dituntut untuk mampu mengatur diri sendiri secara mandiri dengan pendekatan yang sesuai dengan dirinya sehingga ia mampu memotivasi dan mengarahkan diri, (2) guru memfasilitasi dan mengembangkan pengetahuan, keterampilan serta memahami hal-hal yang dibutuhkan, (3) menyediakan media yang memadai, dan (4) memfasilitasi pembelajaran yang kreatif (Chandrawati, 
2010). Artinya pelaksanaan pembelajaran daring menuntut guru untuk lebih kreatif dan inovatif serta memperhatikan karakteristik siswa, semua siswa dapat berhasil mencapai tujuan pembelajaran.

Nakayama dalam penelitiannya menjelaskan bahwa tidak semua siswa berhasil mengikuti e-learning, hal ini difaktori oleh lingkungan belajar dan karakteristik siswa yang bisa saja belum memahami dengan baik manfaat dari $e$ learning dan strategi yang tepat digunakan (Nakayama dkk., 2007). Kesuksesan suatu model atau media pembelajaran dipengaruhi oleh lingkungan belajar dan karakteristik siswa serta pemahaman siswa tentang cara belajar.

Lingkungan belajar maksudnya adalah kualitas pengajaran yang diberikan oleh guru efektif dalam mencapai tujuan yang dikehendaki dari pembelajaran tersebut. Pembelajaran bisa dikatakan berhasil ketika pada prosesnya terjadi interaksi yang baik, serta sesuai dengan tujuan yang direncanakan yaitu siswa menguasai sesuatu hal baru. Prayitno menjelaskan hasil belajar ditandai dengan tidak tahu menjadi tahu, tidak bisa menjadi bisa, tidak mau menjadi mau, tidak biasa menjadi terbiasa, serta tidak bersyukur dan ikhlas menjadi bersyukur dan ikhlas (Prayitno, 2009).

Tercapainya kompetensi perubahan tersebut merupakan tolak ukur keberhasilan kegiatan belajar. Dalam upaya untuk mencapai tujuan dari kegiatan belajar tersebut siswa dituntut lebih aktif, karena aktivitas menjadi tanda adanya kegiatan belajar. Guru berusaha menciptakan suasana pembelajaran yang menyenangkan dan penggunaan alat atau perangkat sesuai dengan materi pelajaran. Misalnya guru dapat memvirtualisasikan materi ajar agar tambah menarik sehingga meningkatkan motivasi siswa masuk ke dalam proses pembelajaran.

Usaha menciptakan suasana pembelajaran yang menyenangkan, merupakan hal yang sulit dilakukan guru. Berdasarkan hasil pengamatan banyak ditemukan siswa dalam kegiatan belajar masih belum terlibat secara aktif,siswa tidak memperhatikan, tidak mendengarkan penjelasan guru, berbicara dengan teman, bahkan terkadang terlihat siswa tidak peduli. Hal ini diperkirakan karena media yang digunakan guru kadang tidak menarik, kebanyakan guru mendominasi proses pembelajaran dengan cara memberikan penjelasan materi tanpa meningkatkan interaksi agar siswa aktif. Sehingga dalam kegiatan belajar tidak terjalin interaksi antara guru dengan siswa, maupun antara sesama siswa. Mudjiono dan Dimyati menjelaskan bahwa keaktifan siswa dalam kegiatan belajar dapat diamati dari kegiatan fisik (membaca, mendengar, menulis,dsb) sampai kegiatan psikis (mengingat pelajaran, pemecahan masalah, menyimpulkan hasil, dsb) (Dimyati \& Mudjiono, 2009).

Salah satu unsur penunjang keberhasilan siswa dalam proses pembelajaran yaitu keaktifan dan mendapatkan hasil belajar maksimal. Deni Afriani Yunita dan Astuti Wijayanti menjelaskan semakin tinggi tingkat keaktifan siswa maka semakin besar hasil yang diperolehnya (Yunita \& Wijayanti, 
2017). Artinya kompetensi yang tercapai dari proses pembelajaran dapat diukur dengan dua indikator yaitu keaktifan siswa selama kegiatan belajar (antusias siswa) dan hasil yang didapatkannya setelah pembelajaran itu selesai.

Uraian di atas memberikan pemahaman bahwa dalam upaya mewujudkan keaktifan siswa dalam kegiatan belajar, tentu ada faktor-faktor yang mempengaruhi perilaku tersebut. Elliott menjelaskan karakteristik siswa, karakteristik guru, performance (kinerja) guru dalam mengajar, serta kondisi lingkungan sekolah merupakan beberapa faktor yang dapat mempengaruhi keaktifan siswa dalam proses pembelajaran (Elliott, 2000). Keterampilan guru dalam meningkatkan keaktifan siswa dalam kegiatan belajar menjadi upaya guru untuk memberikan hasil terbaik.

Bagaimanapun cara pembelajarannya baik secara langsung tatap muka (konvensional), jarak jauh ataupun secara daring, guru mesti memahami bahwa masing-masing metode tersebut memiliki karakteristik sendiri-sendiri, sehingga guru perlu lebih bijak dalam menerapkan metode pembelajaran yang dipilihnya. Gaya mengajar guru memberi pengaruh sebesar $36,6 \%$ dan keterampilan mengelola kelas menyumbang pengaruh $54,5 \%$ terhadap keaktifan belajar siswa (Febrianto, 2013). Artinya performace guru dalam kegiatan belajar akan menjadi penentu sampainya tujuan pembelajaran dan guru mampu membawa siswa ke dalam proses pembelajaran yang sesungguhnya.

Selama masa pandemi COVID-19 proses pembelajaran dilakukan secara jarak jauh dengan memanfaat teknologi yang tersambung dengan jaringan internet. Shashi Dahiya menyatakan bahwa metode pembelajaran yang dilakukan secara online, dengan menggunakan teknologi informasi dan komunikasi mampu mengaktifkan siswa dalam kegiatan belajar dimana dan kapanpun (Dahiya, 2012). Selain mendengarkan materi dari guru, pembelajaran online juga membuat siswa aktif mengamati, melakukan dan mendemosntrasikan. Dengan ini penelitian bertujuan untuk melihat bagaimanakah keaktifaan siswa dalam proses pembelajaran secara daring selama masa pandemi covid19. Dan berimplikasi bagi Guru BK/Konselor sebagai need assesment (analisis kebutuhan) dalam perencanaan, perancangan, melaksanakan dan mengevaluasi program BK.

\section{METODE}

Penelitian ini menggunakan pendekatan kuantitatif dengan metode deskriftif, yang bertujuan mendiskripsikan secara detail fakta atau fenomena secara sistematis, faktual dan akurat. Populasi penelitian dari dua sekolah yaitu 63 orang dari Sekolah Menengah Kejuruan (SMK) Analisis Kesehatan Tunas Bangsa Jakarta dan 81 orang dari Madrasah Aliyah Negeri (MAN) Insan Cendikia Aceh Timur, dengan total jumlah 144 orang siswa. Pengambilan sampe dilakukan dengan teknik proportional random sampling, menginggat semua sekolah melakukan pembelajaran secara daring selama masa pandemi dan ke dua sekolah tersebut memiliki guru BK yang penulis kenali sehingga bisa mengkoordinir 
siswa untuk pengumpulan data. Pengumpulan data dilakukan dengan menyebarkan kuesioners online google form.

Instrumen yang digunakan yaitu instrumen keaktifan siswa oleh Zamratul Aini (2017) berjumlah 28 item dengan indikator keaktifan siswa dari berbagai aspek seperti aktivitas visual, aktivitas lisan, aktivitas mendengarkan, aktivitas menulis, aktivitas emosional, serta aktivitas mental pada proses pembelajaran yang sudah dilakukan pengujian validitas dengan reliabilitas (0,922). Data dianalisis menggunakan rumus persentase sebagai berikut:

$$
P=\frac{f}{-} \times 100
$$

n

Keterangan :

$\mathrm{P}$ : persentase jawaban

$\mathrm{f}$ : frekuensi jawaban

$\mathrm{n}$ : jumlah sampel

Penetapan kriteria tingkat keaktifan siswa menggunakan rumus mean hipotetik sebagai berikut (Irianto, 2010): Interval $=\frac{\text { Data terbesar }- \text { Data terkecil }}{\text { Jumlah Kelompok }}$

Kriteria penskoran tingkat keaktifan siswa dalam proses pembelajara daring kepada lima kriteria, yaitu sangat tinggi, tinggi, sedang, rendah dan sangat rendah.

\section{HASIL TEMUAN}

Perhitungan data keaktifan belajar siswa yang sudah terkumpul dianalisis secara deskriptif, dengan hasil yang dapat dilihat pada Tabel 1.

Tabel 1. Distribusi Frekuensi dan Persentase Keaktifan Siswa

\begin{tabular}{cccc}
\hline Skor & Kategori & F & \% \\
\hline 118 & Sangat Tinggi & 11 & 8 \\
$96-117$ & Tinggi & 77 & 53 \\
$74-95$ & Sedang & 55 & 38 \\
$52-73$ & Rendah & 1 & 1 \\
$\leq 51$ & Sangat Rendah & 0 & 0 \\
& Total & & $\mathbf{1 4 4}$ \\
\hline
\end{tabular}

Distribusi data di Tabel 1 secara umum mengambarkan bahwa keaktifan siswa pada pembelajaran daring selama masa pandemi Covid-19 terdapat 77 orang siswa atau 53\% berada pada kategori tinggi, dan ada 55 orang siswa atau $38 \%$ berada pada kategori sedang.

Jadi lebih dari setengah keaktifan siswa dalam pembelajaran daring berada pada kategori tinggi. Lebih rinci dilihat pada Tabel 2 berikut : 
Tabel 2. Deskripsi Rata-rata (Mean) dan Persentase (\%) Keaktifan Siswa Berdasarkan Indikator

\begin{tabular}{|c|c|c|c|c|c|c|c|c|c|}
\hline \multirow{2}{*}{ No } & \multicolumn{9}{|c|}{ SKOR } \\
\hline & Indikator & Ideal & $\operatorname{Max}$ & Min. & $\Sigma$ & Mean & $\%$ & SD & Ket \\
\hline 1 & Aktivitas Visual (4) & 20 & 20 & 9 & 2155 & 14,97 & 74,95 & 2,49 & $\mathrm{~T}$ \\
\hline 2 & AktivitasLisan (5) & 25 & 24 & 10 & 2448 & 17 & 68,52 & 2,87 & $\mathrm{~T}$ \\
\hline 3 & AktivitasMendengarkan (3) & 15 & 15 & 7 & 1712 & 11,89 & 79,27 & 2,13 & $\mathrm{~T}$ \\
\hline 4 & AktivitasMenulis (8) & 40 & 40 & 15 & 4379 & 30,41 & 76,03 & 4,59 & $\mathrm{~T}$ \\
\hline 5 & AktivitasEmosional (3) & 15 & 15 & 3 & 1289 & 8,95 & 59,67 & 2,06 & $S$ \\
\hline 6 & Aktivitas Mental (5) & 25 & 25 & 9 & 2298 & 15,96 & 63,83 & 2,76 & $S$ \\
\hline & Keseluruhan & 140 & 139 & 53 & 14281 & 99,18 & 70,38 & 16,9 & $\mathrm{~T}$ \\
\hline
\end{tabular}

Tabel 2 memberikan gambaran bahwa secara persentase rata-rata dari semua indikator yaitu $70,38 \%$ yang berarti bahwa keaktifan siswa dalam pembelajaran daring berada pada kategori tinggi. Artinya bahwa siswa masih aktif dalam proses pembelajaran daring. Keaktifan siswa belum optimal di dalam proses pembelajaran daring selama masa pandemi COVID-19.

\section{PEMBAHASAN}

Hasil analisis data penelitian mengambarkan keaktifan siswa berada pada kategori tinggi. Artinya selama proses pembelajaran daring di masa pandemi Covid-19 ini, siswa relatif masih aktif mengikuti kegiatan belajar. Hasil analisis data perindikator menampilkan hasil ratarata keaktifan siswa berkategori tinggi berada pada indikator aktivitas visual (membaca buku terkait topik yang akan dipelajari, membaca materi sebelum mengerjakan tugas, memperhatikan ketika guru menjelaskan materi), Aktivitas mendengarkan (menyimak penjelasan guru, mendengarkan perintah tugas yang diberikan guru), serta indikator di aktivitas menulis (mengerjakan tugas, menyusun laporan atau catatan dengan rapi serta teliti dalam mengerjakan tugas). Indikator aktivitas lisan menunjukan rata-rata keaktifan siswa tinggi yang kecenderungan ke sedang, artinya siswa dalam kegiatan belajar masih relatif aktif bertanya, menyampaikan pendapat dsb, di sisi lain pembelajaran hanya banyak pemberian tugas, sehingga siswa hanya mengerjakan tugas tersebut tapi tidak menanyakan secara langsung apa yang tidak mereka pahami. Kemudian ada dua indikator yang berkategori sedang yaitu aktivitas mental dan aktivitas emosional. Hasil penelitian mengambarkan bahwa masih perlunya upaya mengaktifan siswa dalam proses pembelajaran daring.

Capaian sedang pada indikator aktivitas emosional dan mental mengambarkan bahwa siswa belum maksimal terlibat secara aktif dalam interaksi belajar. Ciri keaktifan siswa dalam proses pembelajaran terlihatpada keberaniaan siswa dalam mengungkapkan pikiran, perasaan dan keinginan serta kemauan. Karena proses pembelajaran seharusnya merupakan aktivitas bersifat 
fisik, aktivitas mental, emosional, dan intelektual, di mana aktivitas tersebut seharusnya saling terikat dan terlibat secara terus menerus (Sardiman, 2008, Hollingsworth \& Lewis, 2008). Jadi siswa yang aktif dalam kegiatan belajar tidak hanya berbentuk fisik seperti siswa hadir dan duduk, terus menyelesaikan tugas, membaca, menulis atau hanya sedekar mendengarkan penjelasan guru, akan, tetapi siswa juga ikut aktif dalam proses analisis, penghayatan atau mengingat, pemecahan masalah, serta sampai membuat keputusan, yang artinya dalam kegiatan belajar siswa juga melibatkan hal psikis/mental dan emosi.

Proses pembelajaran guru dituntut untuk memiliki keterampilan dalam mengaktifkan siswa. Karena pembelajaran akan berjalan efektif apabila siswa yang menjadi objek dalam belajar ikut terlibat secara aktif. Banyak faktor yang bisa memberi pengaruh terhadap keaktifan siswa dalam kegiatan belajar, seperti keterampilan mengelola kelas serta gaya mengajar guru (Febrianto, 2013). Selama masa pandemi metode pembelajaran guru kurang bervariasi. Rata-rata guru hanya memberikan tugas yang harus dikerjakan dan diselesaikan oleh siswa. Hal ini membuat beberapa siswa merasa terbebani, karena harus mengerjakan semua tugas yang sebelumnya bahkan belum ada penjelasan terkait materi tugas tersebut dari guru.

Berdasarkan hasil survey melalui google form yang diberikan, beberapa siswa mengeluhkan hal tersebut, menyampaikan bahwa pembelajaran daring yang dilakukan selama pandemi tidak efektif serta belum mampu memberikan dan menambahkan pemahaman. Firman \& Rahayu (2020) pada penelitiannya kepada mahasiswa juga menampilkan hasil bahwa tidak cukup bagi mahasiswa hanya dengan membaca materi kemudian menyelesaikan tugas, ada beberapa materi yang bersifat komplek perlu ada penjelasan langsung secara verbal dari dosen.

Harapan dan persepsi anak Indonesia terkait belajar di rumah adalah hal yang penting akibat Covid-19, disisi lain berdasarkan hasil survey terdapat $58 \%$ anak Indonesia memiliki rasa tidak menyenangkan menjalani kebijakan belajar dari rumah. Lebih lanjut Ade Nasihudin menjelaskan harapan anak Indonesia yaitu agar guru tidak memberikan tugas terlalu banyak, serta guru harus lebih mengefektifkan komunikasi antara guru dengan siswa (Liputan6.com, 2020).

Proses pembelajaran online yang menjadi perhatian yaitu bagaimana menciptakan kemandirian dan keterampilan belajar siswa. Oknisih dan Suyoto menyatakan bahwa belajar secara online mampu meningkatkan kemandirian siswa (Oknisih \& Suyoto, 2019). Dalam hal ini yang penting diperhatikan yaitu komunikasi antara guru dengan orang tua harus meningkatkan dan efektif sebagai upaya mengembangkan kemandirian belajar siswa dari rumah selama pandemi Covid-19.

Chandrawati menjelaskan bahwa pembelajaran secara daring menuntut siswa untuk mampu mengatur dan mengarahkan diri secara mandiri, setidanya ada empat komponen penting membangun budaya 
belajar; (1) siswa dituntut untuk mampu mengatur diri sendiri secara mandiri dengan pendekatan yang sesuai dengan dirinya sehingga ia mampu memotivasi dan mengarahkan diri, (2) guru memfasilitasi dan mengembangkan pengetahuan, keteram-pilan serta memahami hal-hal yang dibutuhkan, (3) menyediakan media yang memadai, dan (4) memfasilitasi pembelajaran yang kreatif (Chandrawati, 2010). Hal ini sekiranya sesuai dengan pengertian dari pembelajaran tersebut, di mana terdapat tiga unsur, yaitu 1) Subjek (Guru dan siswa) yang aktif dalam aktivitas belajar, 2) adanya aktivitas dan terjalinnya interaksi antar subjek, 3) lingkungan belajar.

Hal diatas sesuai dengan apa yang sampaikan oleh Gagne, Briggs \& Wager bahwa pembelajaran merupakan rangkaian aktivitas yang dirancang untuk terfasilitasinya proses belajar siswa (Gagne, R. M., Briggs, L. J. \& Wagner, W. W., 1992). Jadi, tujuan pembelajaran itu adalah upaya agar siswa belajar. Maka siswa menjadi subjek yang aktif dalam lingkungan belajar. Agar tercapainya tujuan dari pembelajaran tersebut, maka guru berperan dan bertangungjawab dalam memilih, menentukan, serta merancang tatanan kegiatan belajar agar efektif. Maka dari itu, guru harus merencanakan dan merancang kegiatan pembelajaran dengan baik, menentukan metode pembelajaran, mencari model pembelajarann yang tepat, dengan demikian diharapkan siswa berhasil dalam belajarnya.

Upaya guru dalam meningkatkan keaktifan siswa dalam belajar dalam dilakukan dengan berbagai cara, salah satunya dengan memberikan penguatan. Aini dalam penelitiannya menjelaskan bahwa pemberian penguatan dalam proses pembelajaran dapat memberikan konstribusi meningkatkan keaktifan belajar siswa (Aini dkk., 2018). Pemberian penguatan ditujukan kepada perilaku positif yang ditampilkan siswa ketika kegiatan belajar, hal ini memberikan dampakyaitu siswa antusias dan aktif dalam kegiatan belajar (Halik dkk., 2019). Pemberian penguatan kepada siswa ketika menunjukkan perilaku positif, menjadi salah satu bukti performance guru yang baik dalam pembelajaran. Kemudian, Pohan dalam penelitiannya menjelaskan ada tiga bentuk kegiatan belajar untuk meningkatkan respon siswa dalam pembelajaran yaitu: bertanya, menjawab pertanyaan, dan mengemukakan pendapat. Dapat diupayakan dengan meningkatkan kepercayaan diri, mengupayakan siswa mempunyai persepsi yang positif, meningkatkan motivasi berprestasi, kecerdasan emosi dan konsep diri siswa yang dapat diintervensi oleh Guru BK/ Konselor sekolah melalui layanan bimbingan kelompok (Pohan, 2016; Pohan, dkk, 2018; Pohan, Sahputra, Zahra, 2018; Pohan \& Indra, 2020).

Hasil penelitian di atas mengambarkan bahwa ada tuntutan kepada para guru untuk lebih berperan aktif dalam mengevaluasi efektivitas pembelajaran online atau daring yang dilakukan selama pandemi COVID-19 dan seterusnya, serta disesuaikan dengan kebutuhan belajar. Perencanaan dan perancangan kegiatan pembelajaran yang baik, maka diharapkan tercapainya tujuan pemenuhan aspek-aspek 
pembelajaran seperti moral, pengetahuan, dan kecerdasaan, keterampilan, serta estetika (Dai \& Lin, 2020). Hal ini penting dilakukan dan diperhatikan bagi sekolah, karena perubahan pembelajaran tatap muka ke pembelajaran online atau daring secara tidak langsung dapat mempengaruhi daya serap siswa.

Hasil analisis data penilitian ini, dapat dijadikan need assesment (analisis kebutuhan) bagi guru BK/Konselor dalam perencanaan, perancangan, pelaksanaan dan peng-evaluasian program BK. Perencanaan program BK diperlukannya analisis kebutuhan siswa berkenan dengan karakteristik dan lingkungannya. Sehingga bisa dirumuskan perancangan tujuan dalam bentuk perilaku yang dikuasai siswa. Indikator atau item terendah atau yang masuk pada kategori cukup dan sedang bisa dijadikan analisis rasional untuk membuat program dan materi pelayanan BK melalui penyelenggaraan layanan bimbingan dan konseling. Program BK juga memerlukan need assesment lingkungan seperti identifikasi visi misi sekolah, harapan sekolah, harapan orang tua, sarana prasarana pendukung program, dan lainnya. Maka dengan hasil penelitian ini memberikan masukan bagi kebijakan pimpinan sekolah demi kelancaran pelaksanaan program.

Penelitian ini masih terdapat keterbatasan dan kelemahan. Akan lebih baiknya subjek dan lokasi penelitian lebih luas lagi, sehingga hasil generalisasi tidak hanya sebatas subjek dalam penelitian ini saja, yang jumlahnya masih relatif terbatas. Perlu kiranya dilakukan pengembangan bagi peneliti selanjutnya berkenaan dengan variabel lain yang diduga berkontribusi terhadap keaktifan siswa dalam belajar.

\section{SIMPULAN}

Secara umum keaktifan siswa dalam kegiatan belajar daring ketika pandemi Covid-19 berkategori tinggi. Artinya siswa sudah mampu secara aktif mengikuti kegiatan pembelajaran daring. Apabila ditinjau dari aspek indikator keaktifan, setiap indikator relatif belum saling terikat dan terlibat secara terus menerus, walaupun kegiatan visual, mendengar, menulis, lisan sudah baik, tapi disisi lain indikator kegiatan emosional dan mental masih kategori sedang. Hakikatnya proses pembelajaran merupakan kegiatan yang bersifat fisik, mental, emosional, dan intelektual saling terikat dan terlibat secara terus menerus.

\section{DAFTAR PUSTAKA}

Aini, Z., Nirwana, H., \& Marjohan, M. (2018). Kontribusi Penguatan Guru Mata Pelajaran dan Kepercayaan Diri Siswa terhadap Keaktifan Siswa dalam Belajar. Biblio Couns : Jurnal Kajian Konseling Dan Pendidikan, 1(1), 1-11-11. https://doi.org/10.30596/bibliocouns.v1i1 .1941

Chandrawati, S. R. (2010). Pemamfaatan Elearning dalam Pembelajaran. Jurnal Cakrawala Kependidikan, 8(2), 218616.

Coronavirus Update (Live): 21,092,424 Cases and 757,738 Deaths from COVID-19 Virus Pandemic - Worldometer. (t.t.). Diambil 14 Agustus 2020, dari https://www.worldometers.info/coronav irus/?utm_campaign=homeAdUOA?Si 
Dahiya, S. (2012). An eLearning System for Agricultural Education. Indian Research Journal of Extension Education, 12, 132 135.

Dimyati, \& Mudjiono. (2009). Belajar dan pembelajaran. Rineka Cipta.

Elliott, S. N. (Ed.). (2000). Educational psychology: Effective teaching, effective learning (3rd ed). McGraw-Hill.

Febrianto, A. (2013). Pengaruh Keterampilan Mengelola Kelas dan Gaya Mengajar Guru Terhadap Keaktifan Belajar Siswa Kelas XI Materi Pembelajaran Pembangunan Ekonomi SMA Negeri 2 Slawi. Economic Education Analysis Journal, 2(3), Article 3. https://journal.unnes.ac.id/sju/index.php /eeaj/article/view/3138

Firman, F., \& Rahayu, S. (2020). Pembelajaran Online di Tengah Pandemi Covid-19. Indonesian Journal of Educational Science (IJES), 2(2), 81-89. https://doi.org/10.31605/ijes.v2i2.659

Gagne, R. M., Briggs, L. J. \& Wagner, W. W. (1992). Principles of instructional design (Fourth Edition). Holt, Reihhart and Winston.

Halik, A., Prayitno, \& Mudjiran. (2019). Aplikasi Penguatan kepada Siswa di Sekolah: INSIGHT: Jurnal Bimbingan Konseling, $\quad 8(1), \quad 34-50$. https://doi.org/10.21009/INSIGHT.081.04 Irianto, A. (2010). Statistik: Konsep Dasar, Aplikasi, dan Pengembangannya. Jakarta : Kencana Prenada Media Group. Liputan6.com. (2020, April 12). Belajar di Rumah Akibat Corona COVID-19, Ini Pendapat dan Harapan Anak Indonesia. liputan6.com. https://www.liputan6.com/health/read/4 224969/belajar-di-rumah-akibat-coronacovid-19-ini-pendapat-dan-harapananak-indonesia

Moore, J. L., Dickson-Deane, C., \& Galyen, K. (2011). e-Learning, online learning, and distance learning environments: Are they the same? The Internet and Higher Education, 14(2), 129-135. https://doi.org/10.1016/j.iheduc.2010.10.0 01

Nakayama, M., Yamamoto, H., \& Santiago, R. (2007). The Impact of Learner Characteristics on Learning Performance in Hybrid Courses among Japanese Students. Electronic Journal of ELearning, 5(3), 195-206.

Oknisih, N., \& Suyoto, S. (2019). Penggunaan Aplen (Aplikasi Online) Sebagai Upaya Kemandirian Belajar Siswa. Seminar Nasional Pendidikan Dasar, 1(0), Article 0 .

http://eproceedings.umpwr.ac.id/index. php/semnaspgsd/article/view/1056

Pohan, R. A. (2016). Kontribusi Kepercayaan Diri dan Persepsi Siswa Terhadap Kegiatan Merespon dalam Pembelajaran Serta Implikasinya dalam Bimbingan Dan Konseling. Jurnal Penelitian Bimbingan dan Konseling, 1(2), Article 2. https://doi.org/10.30870/jpbk.v1i2.1872

Pohan, R. A., Hayati, R. H., \& Sahputra, D. S. (2018). Kontribusi Motivasi Berprestasi dan Konsep Diri Terhadap Kegiatan Merespon Dalam Pembelajaran Serta Implikasinya Dalam Bimbingan dan Konseling. Wahana Didaktika, 16(2), 145161.

http://dx.doi.org/10.31851/wahanadidak tika.v16i2.1941 
Pohan, R. A., \& Indra, S. (2020). Efektivitas Layanan Bimbingan Kelompok dalam Meningkatkan Kegiatan Merespon Pembelajaran. Islamic Counseling: Jurnal Bimbingan Konseling Islam, 4(1), 17-30. http://dx.doi.org/10.29240/jbk.v4i1.1280

Pohan, R. A., Sahputra, D., \& Zahra, M. T. (2018, April). Kontribusi Kecerdasan Emosi Terhadap Kegiatan Merespon Dalam Pembelajaran. In Prosiding Seminar Nasional Hasil Penelitian (Vol. 1, No. 1, pp. 298-306).

Prayitno. (2009). Dasar Teori dan Praksis Pendidikan. Gramedia Widiasarana Indonesia.

Purwanto, A., Pramono, R., Asbari, M., Hyun, C. C., Wijayanti, L. M., Putri, R. S., \& Santoso, priyono B. (2020). Studi Eksploratif Dampak Pandemi COVID19 Terhadap Proses Pembelajaran Online di Sekolah Dasar. EduPsyCouns: Journal of Education, Psychology and Counseling, 2(1), 1-12.

Tangquan Middle School, Nanjing 210000, Jiangsu, China, Dai, D., Lin, G., \& Tangquan Middle School, Nanjing 210000, Jiangsu, China. (2020). Online Home Study Plan for Postponed 2020 Spring Semester during the COVID-19 Epidemic: A Case Study of Tangquan Middle School in Nanjing, Jiangsu Province, China. Best Evidence of Chinese Education, 4(2), 543-547. https://doi.org/10.15354/bece.20.rp005

Yunita, D., \& Wijayanti, A. (2017). Pengaruh Media Video Pembelajaran Terhadap Hasil Belajar IPA Ditinjau dari Keaktifan Siswa. SOSIOHUMANIORA: Jurnal Ilmiah Ilmu Sosial Dan Humaniora, 3(2),
Article 2. 